\title{
Inorganic and organic geochemical fingerprinting of sediment sources and ocean circulation on a complex continental margin (São Paulo Bight, Brazil)
}

\author{
Michel Michaelovitch de Mahiques ${ }^{1}$, Till Jens Jörg Hanebuth ${ }^{2}$, Renata Hanae Nagai ${ }^{3}$, Marcia Caruso Bícego ${ }^{1}$, \\ Rubens Cesar Lopes Figueira ${ }^{1}$, Silvia Helena Mello Sousa ${ }^{1}$, Leticia Burone ${ }^{4}$, Paula Franco-Fraguas ${ }^{4}$, \\ Satie Taniguchi ${ }^{1}$, Alexandre Barbosa Salaroli ${ }^{1}$, Gilberto Pereira Dias ${ }^{1}$, Denise Menezes Prates ${ }^{1}$, and \\ Maria Eugenia Fernandes Freitas ${ }^{1}$ \\ ${ }^{1}$ Instituto Oceanográfico, Universidade de São Paulo, 05508-120 Praça do Oceanográfico, 191 São Paulo, SP, Brazil \\ ${ }^{2}$ School of Coastal and Marine Systems Sciences, Coastal Carolina University, 290 Allied Drive, Conway, SC 29526, USA \\ ${ }^{3}$ Centro de Estudos do Mar, Universidade Federal do Paraná, 83255-976 Av. Beira-mar, s/n, Pontal do Paraná, Brazil \\ ${ }^{4}$ Facultad de Ciencias, Universidad de La Republica, Iguá, 4225, Montevideo, 11400, Uruguay
}

Correspondence to: Michel Michaelovitch de Mahiques (mahiques@usp.br)

Received: 2 November 2016 - Discussion started: 21 November 2016

Revised: 9 March 2017 - Accepted: 9 March 2017 - Published: 27 March 2017

\begin{abstract}
In this study, we use inorganic (metal) and organic (bulk and molecular) markers in sediment samples of the south-eastern Brazilian margin to investigate the response of geochemical fingerprints to the complex hydrodynamic processes present in the area. Results indicate the potential of export of terrigenous siliciclastic and organic constituents to the upper slope, even in an area with limited fluvial supply.

Metal contents and especially the $\ln (\mathrm{Ti} / \mathrm{Al})$ and $\ln (\mathrm{Fe} / \mathrm{K})$ ratios make it possible to recognise the extension of shelf sediments toward the upper slope. Potassium, here expressed as $\ln (\mathrm{K} / \mathrm{Sc})$ and $\ln (\mathrm{K} / \mathrm{Al})$ ratios used as proxies of illitekaolinite variations, proved to be an important parameter, especially because it allowed us to decipher the imprint of the northward flow of the Intermediate Western Boundary Current (IWBC) in comparison to the southward flows of the Brazil Current (BC) and Deep Western Boundary Current (DWBC).

Using organic matter analyses, we were able to evaluate the extent of terrestrial contributions to the outer shelf and slope, even without the presence of significant fluvial input. In addition, molecular markers signify a slight increase in the input of $\mathrm{C}_{4}$-derived plants to the slope sediments, transported from distant areas by the main alongshore boundary currents, indicating that the terrestrial fraction of the organic matter
\end{abstract}

deposited on the slope has a distinct origin when compared to shelf sediments.

\section{Introduction}

Sedimentary processes at continental margins are controlled by a complex interplay of factors that act on local, regional and global scales (Pratson et al., 2007). The physical and chemical processes that govern a depositional environment leave particular imprints in the sediments. Thus, the spatial distribution of a characteristic sediment composition can be used to decipher the environmental history of an area, in particular in terms of material supply and oceanographic conditions (Boggs, 2005; Nittrouer et al., 2007; Stow et al., 2008; Hernandez-Molina et al., 2009).

The origin and fate of terrigenous sediments in continental margins can be analysed using different proxies, such as elemental composition (Govin et al., 2012), isotopes (Vroon et al., 1995; Lacan and Jeandel, 2005; de Mahiques et al., 2008), magnetic properties (Razik et al., 2015), mineralogy (Petschick et al., 1996; Wahsner et al., 1999; Nagai et al., 2014a), and even grain size (Prins and Weltje, 1999; Holz et al., 2004). 
Also, organic matter can be used in the comprehension of sediment transport, especially in terms of terrigenous versus marine and natural versus anthropogenic sources (Colombo et al., 1989); together with the bulk organic matter (Meyers, 1994; Ruttenberg and Goñi, 1997), molecular markers are considered reliable proxies for the determination of the origin and characteristics of the organic fraction. The terrigenous / aquatic ratio (TAR) (Bourbonniere and Meyers, 1996) and the average chain length (ACL) (Ficken et al., 2000) are frequently used as proxies for the terrestrial versus marine sources. Also, the Alkane Index (AI) (Schefuß et al., 2003) is considered a useful tool for the evaluation of the relative contribution of $\mathrm{C}_{3}$ and $\mathrm{C}_{4}$ plants. Finally, the Carbon Preference Index (CPI) (Eglinton et al., 1962), originally used as an indicator of natural and anthropogenic sources, can also be used in the determination of the terrigenous or marine character of the organic matter.

The sources of regional continental slope surface sediments in the tropical and subtropical Atlantic were evaluated by Govin et al. (2012) by determining the concentrations of major elements ( $\mathrm{Ca}, \mathrm{Fe}, \mathrm{Al}, \mathrm{Si}, \mathrm{K}, \mathrm{Ti}$ ) and some common metal/metal ratios. In their study, the values of $\ln (\mathrm{Ti} / \mathrm{Al})$ and $\ln (\mathrm{Fe} / \mathrm{K})$ were considered as valuable proxies for the identification of sediment sources, and an allochthonous character of the sediments on the continental slope off south-eastern Brazil was suggested. However, the study had limited sensitivity for the dynamics of regional circulation patterns.

In this context, it is important to highlight that water masses (i.e. bodies of water with similar physical properties), considered major players by some preceding studies (Razik et al., 2015), do not physically contribute to lateral transport of particles, unlike ocean currents (i.e. continuous and directed movement of a water mass).

In fact, previous studies (de Mahiques et al., 2008; FrancoFraguas et al., 2014; Razik et al., 2015) provide different and contradictory interpretations for the sources and transport of sediment in the south-western Atlantic; this is especially due to a complex hydrodynamics of the Subtropical Gyre (Boebel et al., 1999; Schmid et al., 2000; Biló et al., 2014) between 23 and $35^{\circ} \mathrm{S}$.

In this sense, considering the complex hydrodynamics of the south-eastern Brazilian margin north of $28^{\circ} \mathrm{S}$, this study analyses a new data set of both organic and inorganic sediment parameters, collected from the inner shelf to the middle slope. The following main questions are addressed.

- Despite the "sediment-starved" character off the inner shelf, is the deep ocean a potential destination of coastal sediments?

- Can inorganic and organic geochemical signatures help to differentiate coastal sediments from shelf and slope sediments?
- Is it possible to differentiate distinct geochemical signatures in the sediments that reflect the various ocean current systems on the south-eastern Brazilian slope, namely the BC, IWBC and DWBC?

\section{Study area}

\subsection{Geology}

The study area corresponds to the central part of the São Paulo Bight, as defined by Zembruscki (1979). It extends from $23^{\circ} 30^{\prime} \mathrm{S}$ to $26^{\circ} 00^{\prime} \mathrm{S}$ and from $44^{\circ} 00^{\prime} \mathrm{W}$ to $46^{\circ} 00^{\prime} \mathrm{W}$ (Fig. 1). A complex coastline, including Precambrian headlands, islands consisting of crystalline rocks, pocket beaches and small-scale bays and estuaries, defines the inner boundary of the study area. The latter occur in coastal plains and are filled with Eemian (Marine Isotope Stage 5e) and midto-late Holocene sea-level highstand sediments (Suguio and Martin, 1978).

The south-eastern Brazilian margin has its origin in the geological evolution as an Atlantic-type continental margin. It is marked by Cretaceous to recent subsidence of the Santos Basin (Meisling et al., 2001) associated with intensive Mesozoic alkaline magmatism, and by uplift of the Serra do Mar mountain range (Almeida and Carneiro, 1998). The maximum thickness of the sedimentary successions reaches $12 \mathrm{~km}$, represented by a variety of depositional environments ranging from terrestrial to deep ocean (Nunes et al., 2004).

\subsection{Oceanography and sedimentary processes}

The South Atlantic Subtropical Gyre, during its movement toward the Brazilian continental margin, is influenced by both the wind field and the southern circulation in the South Atlantic. At the near-surface level (carrying Tropical Water $\mathrm{TW}$ ), the gyre is centred at $15^{\circ} \mathrm{S}$. At the level of the thermocline (carrying South Atlantic Central Water - SACW), the gyre is centred at $20^{\circ} \mathrm{S}$. Finally, at the underlying intermediate level, between 500 and $1200 \mathrm{~m}$ water depth (carrying Antarctic Intermediate Water - AAIW), the gyre approaches the margin at $28^{\circ} \mathrm{S}$ (Schmid et al., 2000).

This slopeward-directed intermediate water flow leads to the occurrence of an unparalleled oceanographic phenomenon at the upper slope, which is known as the Santos Bifurcation (Boebel et al., 1997, 1999) (Fig. 1). From a hydrodynamic point of view, the Santos Bifurcation leads to the formation of a permanent western boundary current (Intermediate Western Boundary Current - IWBC) (Boebel et al., 1999; Silveira et al., 2004; Legeais et al., 2013; Biló et al., 2014; Schattner et al., 2016) which leads to a reversed flow compared to the regional southward-directed circulation (Brazil Current - BC). Thus, a unique situation in the global ocean occurs. In this situation, an intermediate water mass, transported by a boundary current, runs opposite to the 

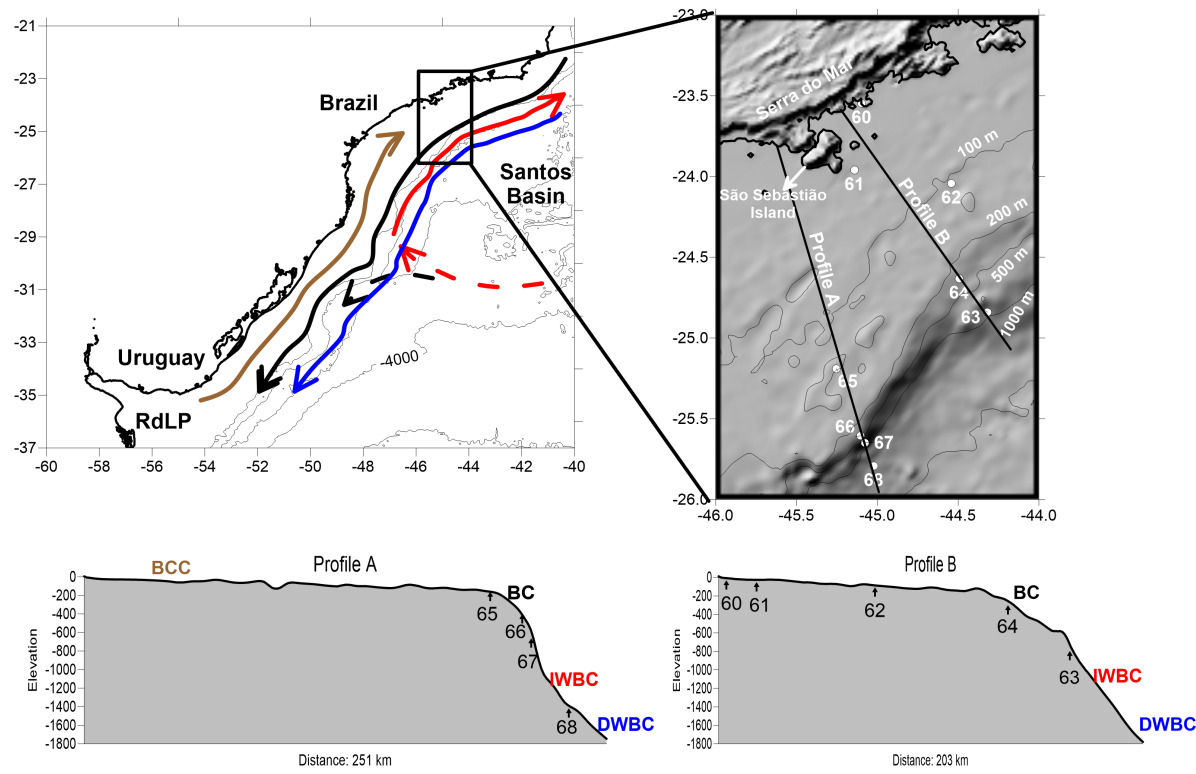

Figure 1. Location of the south-western Atlantic margin with a zoom to the study area and sampling stations. RdLP refers to Rio de La Plata. Arrows refer to the main current systems in the area: Brazilian Coastal Current (BCC) - brown; Brazil Current (BC) - black; Intermediate Western Boundary Current (IWBC) - red; Deep Western Boundary Current (DWBC) - blue. The dashed line corresponds to the approximate position of the Santos Bifurcation (Boebel et al., 1999).

surface circulation, which leads to the generation of a transition zone in which the current velocities tend to be zero (Biló et al., 2014). According to Schmid et al. (2000), about onefourth of the $19 \mathrm{~Sv}$ that reach the Brazilian margin at the Santos Bifurcation turns to the north, thus diverting water from the South Atlantic Gyre. Another flow inversion occurs at 1200-1300 m water depth at the interface between the IWBC and Deep Western Boundary Current (DWBC), which transports North Atlantic Deep Water (NADW) toward the south (Stramma and England, 1999).

The southern Brazilian upper margin is characterised by the confluence of two main current systems. The outer shelf and upper slope are dominated by the southward flow of the Brazil Current (BC) (de Mahiques et al., 2004). The inner shelf, in contrast, is controlled by the northward flowing Brazilian Coastal Current (BCC) (de Souza and Robinson, 2004). The BCC transports in part sediments from the Rio de la Plata (de Mahiques et al., 2008) river plume (Möller et al., 2008). This seasonal wind-dependent northward displacement of colder and less saline waters also controls the variability in regional primary productivity of the area (Ciotti et al., 1995).

Razik et al. (2015), using 25 sediment surface samples collected between 20 and $45^{\circ} \mathrm{S}$, proposed a conceptual sourceto-sink sediment model for the south-western Atlantic region, enhancing the role of Pampean (Argentina) originated sediments for the sediment cover on the south-western Brazilian slope. It is, however, important to note that their water mass distribution model is not in agreement with the complex hydrodynamic situation along the south-western At- lantic continental margin, especially on the south-eastern Brazilian slope, as discussed later.

Sedimentation along the south-eastern Brazilian continental margin (Fig. 1) is controlled by coastal hydrodynamic processes, which are strongly associated with the local winddriven current system, by the northward-directed plume of the Río de La Plata on the inner and mid shelf, and by the meandering eddy structure of the southward flowing Brazil Current on the outer shelf, which itself is a result of upwelling dynamics, occasionally driven by passing $\mathrm{BC}$ meanders and local wind conditions (de Mahiques et al., 2004, 2008, 2011). Apart from the detection of the presence of sediments derived from the Río de La Plata as far north as $25^{\circ} \mathrm{S}$, few studies have addressed material sources or transport and sedimentation mechanisms in this region (de Mahiques et al., 2008; Razik et al., 2015). The understanding of sediment sources, transport and deposition is nevertheless of high relevance in this region, because major parts of the continental shelf have originally been considered sediment-starved (Kowsmann and Costa, 1979).

Late Holocene sedimentation rates on the continental shelf and slope vary from 2 to $68 \mathrm{~cm} \mathrm{ka}^{-1}$ (de Mahiques et al., 2011). In the southern sector of the shelf, sedimentation is strongly influenced by terrigenous supply from the remote Rio de la Plata outflow, which leads to the formation of a number of inner- and mid-shelf mud depocentres (de Mahiques et al., 2016). The lowest sedimentation rates occur on the outer shelf and around the shelf break, confirming the strong dependency of these sedimentary processes on the coupled BC-IWBC system (de Mahiques et 
al., 2011). The sediment distribution exhibits latitudinal variations and bathymetric control. The area off São Sebastião $\left(24^{\circ} \mathrm{S}-45^{\circ} 30^{\prime} \mathrm{W}\right)$ marks a regional boundary between two main sedimentary provinces that are characterised by differences in organic (bulk $\delta^{13} \mathrm{C}$ ) and inorganic (clay mineralogy, metal) compositions (de Mahiques et al., 1999; Nagai et al., 2014a, b).

South of São Sebastião, depositional processes are related to the northernmost penetration of shelf waters associated with the Rio de la Plata freshwater plume. This coastal plume, carried northwards along the southern Brazilian shelf by the BCC (de Souza and Robinson, 2004), has been identified as far north as $24^{\circ} \mathrm{S}$ (Campos et al., 1999). However, $\mathrm{Nd}$ and $\mathrm{Pb}$ isotope data indicate that the influence of the Rio de la Plata outflow is strongly limited south of $28^{\circ} \mathrm{S}$, with the sector between 28 and $24^{\circ} \mathrm{S}$ being a transitional zone (de Mahiques et al., 2008). North of $24^{\circ}$ S, i.e. off São Sebastião, the heterogeneity of sediments is related to more complex hydrodynamics, especially on the inner and middle shelves, where a diversified ocean structure interacts with the local seafloor morphology, the presence of islands, the concave shape of the coastline and the presence of a BC branch meander, which leads to a highly complex oceanographic situation (Silveira et al., 2000; Dottori and Castro, 2009).

In addition, the sedimentary processes exhibit a conspicuous bathymetric control. For instance, on the inner shelf, Holocene sedimentation has levelled the irregular relief which itself developed during lower sea level (Nagai et al., 2014a), whilst on the outer shelf, low sedimentation rates and very local sand fields are associated with the main flow of the $\mathrm{BC}$ which acts as a "floor-polisher" here (de Mahiques et al., 2004).

On the continental slope, the bathymetric configuration generally indicates a variable morphology, with slope gradients between $1: 10$ and $1: 100$. An amphitheatre-shaped feature has developed south-east of São Sebastião $\left(24^{\circ} 30^{\prime}\right.$ S$44^{\circ} 00^{\prime} \mathrm{W}$ and $26^{\circ} 30^{\prime} \mathrm{S}-46^{\circ} 00^{\prime} \mathrm{W}$ ), where alternating concave and convex isobath contours indicate a history of a partly failing prograding slope process (Maia et al., 2010; Reis et al., 2013).

The coverage of sediment samples on the slope is still incipient and heavily concentrated on its upper part. The shelf break/upper slope transition zone shows sandy sediments with high concentrations of biolithoclastic and bioclastic sediments (de Mahiques et al., 2011). The sparse sediment samples from the middle and lower slopes do not allow for a proper characterisation of the sedimentary cover. Seismic lines interpreted by Maia et al. (2010) nevertheless show wavy and chaotic internal reflectors that indicate gravitydriven mass movement deposits in areas with a higher slope gradient.

\section{Material and methods}

In this study, we used 107 sediment samples collected from eight multi-cores (MUCs) and one Van Veen grab sampler, from the inner shelf to the middle slope off the south-eastern Brazilian margin (Table 1, Fig. 1). The MUC samples were sliced into $1 \mathrm{~cm}$ intervals, frozen and later freeze-dried.

Approximately $10 \mathrm{mg}$ of planktonic foraminifera $\mathrm{Glo}$ bigerinoides ruber and $G$. sacculifer tests $(>150 \mu \mathrm{m}$ size fraction) from six of the cores (NAP-62, -63, -64, -65, -66, -68) were AMS dated at Beta Analytic Laboratories. Following Lund et al. (2015), we applied a regional reservoir age correction $(\Delta R)$ of $7 \pm 200$ years $(1 \sigma)$ to account for unknown changes in the reservoir age through time. Calendar ages were calibrated using Calib v.7.1 (http://calib.qub.ac.uk/ calib/calib.html) (Table 2). Core tops were considered modern since it was possible to verify that the sediment-water interfaces remained intact during core sampling.

Metals (Al, Ba, Ca, Fe, K, Mg, Sc, Sr, Ti, V) were analysed with a Varian 710 ICP-OES, following the procedures of total digestion established in the US Environmental Protection Agency 3052 Method. About $0.25 \mathrm{~g}$ of dry sediment were weighted and inserted in a Teflon digestion tube, together with $10 \mathrm{~mL}$ of concentrated $\mathrm{HNO}_{3}$. The mixture was digested by microwave digestion for $20 \mathrm{~min}$. Then, 2 to $5 \mathrm{~mL}$ of $40 \% \mathrm{HF}$ were added and the digestion procedure was repeated. Finally, $1 \mathrm{~mL}$ of $30 \% \mathrm{H}_{2} \mathrm{O}_{2}$ was added and the digestion procedure was repeated once more. The solution was then filtered through Whatman no. 40 filters. The filtrate was transferred to a Teflon beaker and heated on a hot plate until evaporation. Then, $20 \mathrm{~mL}$ of $5 \% \mathrm{HNO}_{3}$ were added three times and evaporated and the remnant residue was transferred to a $50 \mathrm{~mL}$ flask with distilled water and the solution analysed by ICP-OES. The accuracy of the results was verified by digestion of aliquots of the NIST Estuarine Sediment SRM1646a certified standard.

For data analysis and interpretation of metal concentrations, two approaches were used in this study. First, we used the same logarithm of the ratios presented in Govin et al. (2012), with the exception of the $\ln (\mathrm{Al} / \mathrm{Si})$, since $\mathrm{Si}$ was not analysed in this study. We also used the $\mathrm{Ca} / \mathrm{Al}$ ratio (Sun et al., 2008) and $\mathrm{K} / \mathrm{Al}$ ratio (Plewa et al., 2012), here presented in their logarithmic forms, as secondary approximations for the relative contribution of sediment sources.

A second approach consisted of a principal component analysis (PCA), using metal contents. The PCA was performed on the correlation matrix, using PAST version 3.14 software (Hammer et al., 2001).

Bulk organic parameters $\left(\mathrm{C}_{\text {org }}\right.$ and $\mathrm{N}_{\text {tot }}$ concentrations; $\delta^{13} \mathrm{C}_{\mathrm{PDB}}$ and $\delta^{15} \mathrm{~N}_{\mathrm{AIR}}$ isotopes) were determined using a Finnigan Delta V Plus mass spectrometer coupled with a Costech Elemental Analyser. Reference materials used to control the quality of data obtained are presented as the Supplement. $\mathrm{CaCO}_{3}$ content was determined by the weight dif- 
Table 1. Position of the samples analysed in this work.

\begin{tabular}{lllllrr}
\hline Station & Sampling device & Date $(\mathrm{d} / \mathrm{m} / \mathrm{yr})$ & Lat & Long & Water depth $(\mathrm{m})$ & Sediment depth $(\mathrm{cm})$ \\
\hline 60 & Van Veen & $24 / 02 / 2013$ & $23^{\circ} 32.745 \mathrm{~S}$ & $45^{\circ} 05.900 \mathrm{~W}$ & 16 & Surface \\
61 & Multiple corer & $25 / 02 / 2013$ & $23^{\circ} 57.600 \mathrm{~S}$ & $45^{\circ} 08.500 \mathrm{~W}$ & 52 & 23 \\
62 & Multiple corer & $25 / 02 / 2013$ & $24^{\circ} 02.532 \mathrm{~S}$ & $44^{\circ} 32.540 \mathrm{~W}$ & 121 & 28 \\
63 & Multiple corer & $26 / 02 / 2013$ & $24^{\circ} 50.400 \mathrm{~S}$ & $44^{\circ} 19.110 \mathrm{~W}$ & 840 & 35 \\
64 & Multiple corer & $26 / 02 / 2013$ & $24^{\circ} 37.891 \mathrm{~S}$ & $44^{\circ} 29.635 \mathrm{~W}$ & 302 & 15 \\
65 & Multiple corer & $26 / 02 / 2013$ & $25^{\circ} 11.363 \mathrm{~S}$ & $45^{\circ} 15.217 \mathrm{~W}$ & 121 & 21 \\
66 & Multiple corer & $27 / 02 / 2013$ & $25^{\circ} 36.291 \mathrm{~S}$ & $45^{\circ} 06.235 \mathrm{~W}$ & 368 & 15 \\
67 & Multiple corer & $27 / 02 / 2013$ & $25^{\circ} 38.844 \mathrm{~S}$ & $45^{\circ} 04.629 \mathrm{~W}$ & 649 & 40 \\
68 & Multiple corer & $27 / 02 / 2013$ & $25^{\circ} 47.532 \mathrm{~S}$ & $45^{\circ} 01.343 \mathrm{~W}$ & 1393 & 40 \\
\hline
\end{tabular}

Table 2. AMS radiocarbon datings of the multiple cores. $\Delta R=7 \pm 200$ (Lund et al., 2014).

\begin{tabular}{lrrrr}
\hline Sample & Lab ID & $\begin{array}{r}\text { Conventional } \\
\text { age }(\mathrm{yr} \mathrm{BP}) \pm 1 \sigma\end{array}$ & $\begin{array}{r}\text { Median probability and } \\
2 \sigma \text { cal range }(\mathrm{yr} \mathrm{BP})\end{array}$ & $\begin{array}{r}\text { Average sedimentation } \\
\text { rates }\left(\mathrm{cm} \mathrm{kyr}^{-1}\right)\end{array}$ \\
\hline NAP62-2_22 & 368261 & $1880 \pm 30$ & $1445(1250-1487)$ & 17.1 \\
NAP63-2_25 & 368262 & $4330 \pm 30$ & $4450(4183-4508)$ & 6.0 \\
NAP64-2_16 & 368263 & $4560 \pm 30$ & $4750(4513-4812)$ & 3.6 \\
NAP65-2_19 & 368264 & $2420 \pm 30$ & $2060(1824-2106)$ & 10.2 \\
NAP66-2_23 & 368265 & $5140 \pm 30$ & $5475(5296-5551)$ & 4.4 \\
NAP68-2_37 & 368266 & $3230 \pm 30$ & $3045(2780-3095)$ & 12.6 \\
\hline
\end{tabular}

ference of the sediments before and after acidification with $10 \% \mathrm{HCl}$.

For the analysis of $n$-alkanes we used the analytical procedure employed by Bicego et al. (2006). Three grams of dry sediment were extracted with methylene chloride and $n$ hexane $(1: 1, v / v)$ using a Soxhlet apparatus, after adding $n$-hexadecene and $n$-eicosene as surrogates. Aliphatic hydrocarbons and alkenones were separated from the total lipid fraction by column chromatography using $5 \%$ deactivated alumina $(1 \mathrm{~g})$ and silica $(2 \mathrm{~g})$. The elution was done with $6 \mathrm{~mL}$ of $n$-hexane and $10 \mathrm{~mL}$ of DCM : $n$-hexane $(9: 2, v / v)$. Tetradecene was then added as an internal standard.

Aliphatic hydrocarbons were analysed by gas chromatography (Agilent GC model 6890) by flame ionisation detection (GC-FID). The column used was a fused silica column coated with $5 \%$ diphenyl/dimethylsiloxane $(50 \mathrm{~m}, 0.32 \mathrm{~mm}$ ID and $0.17 \mathrm{~mm}$ film thickness). Hydrogen was used as the carrier gas. The oven temperature was programmed to increase from 40 to $60^{\circ} \mathrm{C}$ at $20^{\circ} \mathrm{C} \mathrm{min}^{-1}$, to $250^{\circ} \mathrm{C}$ at $5^{\circ} \mathrm{C} \mathrm{min}^{-1}$, to $300^{\circ} \mathrm{C}$ at $20^{\circ} \mathrm{C} \mathrm{min}^{-1}$, and finally to $320^{\circ} \mathrm{C}$ at $6^{\circ} \mathrm{C} \mathrm{min}^{-1}$, where it was held for $20 \mathrm{~min}$. Aliphatic hydrocarbons ( $n$-alkanes from $\mathrm{C}_{12}$ to $\mathrm{C}_{34}$, phytane and pristane) were identified by matching the retention times with data measured using standard mixtures of $\mathrm{HCs}$ from AccuStandard (USA).

Quality assurance and quality control were performed based on the analysis of the procedural blank, blank spike, matrix spike, standard reference material (IAEA-417, International Atomic and Energy Agency) and internal standard recovery. The average recovery for internal standards was $72 \%(50-106 \%)$ and recovery in the spike blank and spiked samples varied from 62 to $101 \%$ and from 51 to $112 \%$, respectively. Concentrations found in the blanks were subtracted from all samples. Certified standards at five different concentrations were injected to build analytical curves with correlations of at least 0.995 . The method detection limit was based on the standard deviation of seven replicates and varied from 0.005 to $0.017 \mu \mathrm{g} \mathrm{g}^{-1}$.

The following $n$-alkane-based indexes were used in this study.

1. Terrigenous/aquatic ratio (TAR) (Bourbonniere and Meyers, 1996):

$\mathrm{TAR}=\frac{\sum \mathrm{C}_{27+29+31}}{\sum \mathrm{C}_{15+17+19}}$

This index is based on the assumption that photosynthetic algae and bacteria are characterised by short-chain $n$-alkanes $\left(\mathrm{C}_{17}\right)$ when compared with the

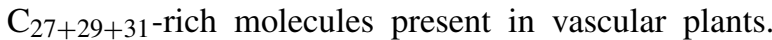
Bourbonniere and Meyers (1996) observed that despite the fact that the TAR index may over-represent the absolute amounts from terrigenous sources, it can be used as a qualitative proxy for the relative contributions of organic matter from both terrestrial areas and aquatic sources. 
2. Terrestrial $n$-alkanes Index (TI) (this paper):

$\mathrm{TI}=\frac{\Sigma \mathrm{C}_{27+29+31}}{\mathrm{C}_{\mathrm{org}}}$.

This estimation is based on the same assumption as described above (TAR), but is calculated as a ratio over the total organic carbon $\left(\mathrm{C}_{\text {org }}\right)$ content. This parameter is based on the assumption that greater values of TI represent a higher input of terrestrial organic matter.

3. Alkane Index (AI) (Schefuß et al., 2003):

$\mathrm{AI}=\frac{n \mathrm{C}_{31}}{n \mathrm{C}_{31}+n \mathrm{C}_{29}}$.

Used here as a proxy for the climatic conditions in the source area for organic carbon, $\mathrm{C}_{31}$ is assumed to be more common in tropical dry areas than $\mathrm{C}_{29}$, which is more abundant in temperate climates (Horikawa et al., 2010). According to Zhang et al. (2006), AI values higher than 0.5 indicate an influence of grasses $\left(C_{4}\right.$ plants) as organic carbon sources. On the other hand, AI values lower than 0.5 indicate that the terrestrial organic matter is derived from $\mathrm{C}_{3}$ plants (Rommerskirchen et al., 2006).

4. Average chain length (ACL) (Ficken et al., 2000):

$\mathrm{ACL}=\frac{\sum\left[\mathrm{C}_{i}\right] \cdot i}{\sum\left[\mathrm{C}_{i}\right]}$.

Here, $\mathrm{C}_{i}$ is the $n$-alkane with $i$ number of carbons, varying from 25 to 33, and describes the average number of carbon atoms per molecule based on the abundance of the odd-carbon-numbered higher plant $n$ alkanes (Poynter and Eglinton, 1990; Jeng, 2006). Used as a proxy of terrestrial organic matter input, values of ACL between 25 and 33 represent a higher contribution of terrestrial plants (Collister et al., 1994; Rommerskirchen et al., 2006). The ACL values of $n$-alkanes can also be used to show the distribution of $\mathrm{C}_{3}$ and $\mathrm{C}_{4}$ plants (Rommerskirchen et al., 2006; Vogts et al., 2009).

5. Carbon Preference Index (CPI) (Eglinton et al., 1962; Eglinton and Hamilton, 1963; Aboul-Kassim and Simoneit, 1996):

$\mathrm{CPI}=\frac{1}{2} \times$

$\left(\frac{\left[n-\mathrm{C}_{25}\right]+\left[n-\mathrm{C}_{27}\right]+\left[n-\mathrm{C}_{29}\right]+\left[n-\mathrm{C}_{31}\right]+\left[n-\mathrm{C}_{33}\right]}{\left[n-\mathrm{C}_{24}\right]+\left[n-\mathrm{C}_{26}\right]+\left[n-\mathrm{C}_{28}\right]+\left[n-\mathrm{C}_{30}\right]+\left[n-\mathrm{C}_{32}\right]}\right.$

$\left.+\frac{\left[n-\mathrm{C}_{25}\right]+\left[n-\mathrm{C}_{27}\right]+\left[n-\mathrm{C}_{29}\right]+\left[n-\mathrm{C}_{31}\right]+\left[n-\mathrm{C}_{33}\right]}{\left[n-\mathrm{C}_{26}\right]+\left[n-\mathrm{C}_{28}\right]+\left[n-\mathrm{C}_{30}\right]+\left[n-\mathrm{C}_{32}\right]+\left[n-\mathrm{C}_{34}\right]}\right)$

Even though this index is widely used to differentiate natural and anthropogenic sources of organic matter (Pietrogrande et al., 2010), it is also considered a proxy of marine (CPI lower than 1.5) versus terrestrial (CPI higher than 2.3) contributions (Collister et al., 1994; Bi et al., 2005).
6. Pristane / phytane ratio (Pri / Phy): in recent sediments, this parameter is usually used to identify the organic matter source (Rashid, 1979). This ratio is also thought to be an indicator of depositional conditions and the relative degree of alteration or degradation of organic matter (Powell and McKirdy, 1973; Didyk et al., 1978). It was also used in other works as a proxy for bottom redox conditions. According to Didyk et al. (1978), values of Pri / Phy lower than 1 indicate anoxic water above anoxic sediments; in contrast, fully oxic conditions provide Pri / Phy values higher than 1 . This ratio can also be affected by the presence of bacterial material (Volkman and Maxwell, 1986; Ten Haven et al., 1988).

As mentioned above, we also performed a PCA on the data, using the molecular parameters cited above as variables.

\section{Results and discussion}

All cores dated display late Holocene ages (Table 2). Assuming that the core tops are modern as explained above, calculated average sedimentation rates vary from $3.6 \mathrm{~cm} \mathrm{kyr}^{-1}$ (core 64) to a maximum of $17.1 \mathrm{~cm} \mathrm{kyr}^{-1}$ (core 62) (Table 2). It is worth noting that despite the value of the sedimentation rate obtained for core 65 , the visual description (under a stereo-microscope) of the sediments (taken at $121 \mathrm{~m}$ water depth) showed stained and oxidised bioclasts as well as limonite-covered quartz grains, which are indicative of relict sediment facies (Wilson, 2010). Indeed, the area where core 65 was retrieved from was previously described as covered by relict sediments (de Mahiques et al., 2004). Results of both inorganic and organic analyses are presented as Supplements 2,3 , and 4 .

\subsection{Inorganic parameters}

The $\ln (\mathrm{Ti} / \mathrm{Ca})$ and $\ln (\mathrm{Ca} / \mathrm{Al})$ ratios show the expected inverse patterns (Fig. 2a). Lower values of $\ln (\mathrm{Ti} / \mathrm{Ca}$ ) and higher $\ln (\mathrm{Ca} / \mathrm{Al})$ ratios $(-4.44 \pm 0.19$ and $1.81 \pm 0.16$, respectively) were measured in core 65 (121 m water depth), which corresponds to the relict facies mentioned above. A higher terrigenous influence was found in core $61(60 \mathrm{~m}$ water depth, $\ln (\mathrm{Ti} / \mathrm{Ca})=-2.06 \pm 0.06 ; \ln (\mathrm{Ca} / \mathrm{Al})=$ $-0.51 \pm 0.10)$, located on the inner shelf. In general, midslope sediments (samples 67 and 68) show a higher terrigenous contribution when compared with the outer-shelf and upper-slope samples.

The $\ln (\mathrm{Ti} / \mathrm{Al})$ and $\ln (\mathrm{Fe} / \mathrm{K})$ ratios (Fig. 2b) show a higher variability, especially on the continental slope. The $\ln (\mathrm{Ti} / \mathrm{Al})$ ratio allows a clear distinction of samples 67 $(649 \mathrm{~m},-2.81 \pm 0.02)$ and $68(1393 \mathrm{~m},-2.80 \pm 0.06)$ from the rest, including sample 63, which is located at an intermediate water depth $(840 \mathrm{~m},-2.66 \pm 0.08)$. In the same way, samples 67 and 68 show distinct $\ln (\mathrm{Fe} / \mathrm{K})$ ratios $(0.88 \pm 0.08$ and $0.93 \pm 0.03$, respectively) compared to 

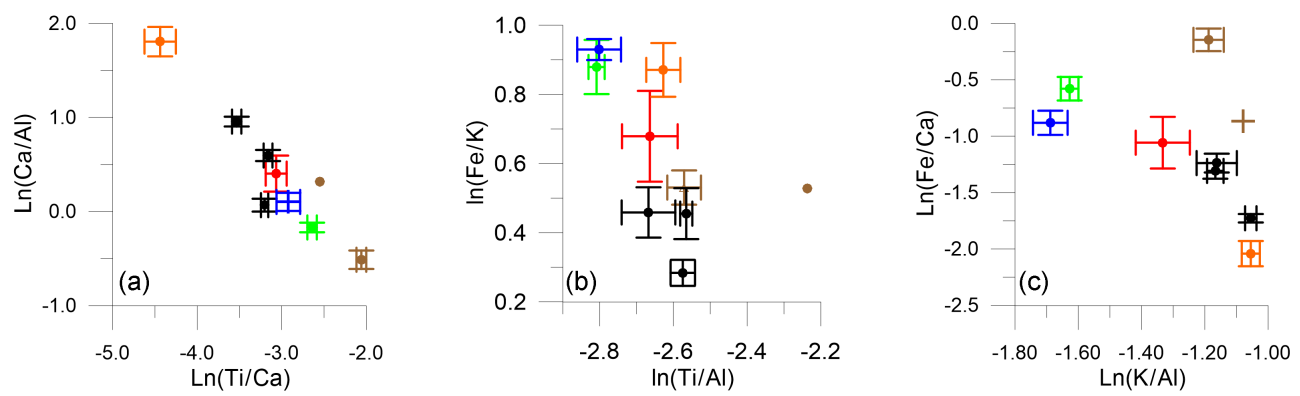

Figure 2. Scatter plots of average \pm standard deviation of (a) $\ln (\mathrm{Ca} / \mathrm{Al})$ versus $\ln (\mathrm{Ti} / \mathrm{Ca})$; (b) $\ln (\mathrm{Fe} / \mathrm{K})$ versus $\ln (\mathrm{Ti} / \mathrm{Al})$; and (c) $\ln (\mathrm{Fe} / \mathrm{Ca})$ versus $\ln (\mathrm{K} / \mathrm{Al})$. Colours refer to samples from the coast and inner shelf (brown), outer shelf and upper slope (black), relict outer shelf sediment (orange), upper slope - SACW (green), middle slope - IWBC (red) and middle slope - DWBC (blue).

the rest of the samples, except for sample 65, indicating a stronger kaolinitic influence. Samples from the shelf and upper slope show higher $\mathrm{K}$ contents (lower values of $\ln (\mathrm{Fe} / \mathrm{K}))$.

Differing compositions of shelf and mid-slope sediments are also observed in the plot of $\ln (\mathrm{K} / \mathrm{Al})$ versus $\ln (\mathrm{Fe} / \mathrm{Ca})$, especially considering the former parameter (Fig. 2c). Once more, there is a discrepancy of samples $67(649 \mathrm{~m})$ and 68 $(1393 \mathrm{~m})$ when compared with sample $63(840 \mathrm{~m})$, i.e. located in a bathymetrically intermediate position.

The first two PCA components for the metal data (Fig. 3) account for $89.8 \%$ of the total variance (first: $79.0 \%$; second: $10.8 \%$ ). Results clearly separate the carbonate-rich relict sediments on the outer shelf (core 65, $121 \mathrm{~m}$ water depth) from the siliciclastic sediments from both shelf and slope. In addition, while the sediments on the shelf and upper slope are rich in $\mathrm{K}, \mathrm{Ba}$ and $\mathrm{Ti}$, cores $67(649 \mathrm{~m})$ and $68(1393 \mathrm{~m})$ are relatively enriched in $\mathrm{V}, \mathrm{Fe}$ and $\mathrm{Mg}$. It is important to note that the sediments from core 63 (840 m water depth) exhibit a transition between these two geochemical characteristics.

\subsection{Organic parameters}

We used the $\mathrm{N} / \mathrm{C}$ ratio as a bulk organic proxy indicating terrestrial input (Perdue and Koprivnjak, 2007; Biscara et al., 2011) and compared it with the $\delta^{13} \mathrm{C}$ (Fig. 4a) and $\delta^{15} \mathrm{~N}$ values (Fig. 4b). In both figures, it is possible to recognise two distinct patterns, corresponding to shelf and upper slope samples on one side of the plots, and middle slope sediments on the other. Shelf and upper slope sediments show an expected increase in $\mathrm{N} / \mathrm{C}$ ratios associated with increasing $\delta^{13} \mathrm{C}$ (Fig. 4a) and $\delta^{15} \mathrm{~N}$ values (Fig. 4b). On the other hand, middle slope samples show no variation in $\mathrm{N} / \mathrm{C}$ ratios, independent of the isotope values. This distinct aspect is probably related to the depletion of nitrogen due to organic matter recycling in the deeper sediments off Brazil (Metzler et al., 1997), as well as to the availability of nitrogen during seasonal upwelling processes on the shelf (Sumida et al., 2005; Moser et al., 2014).

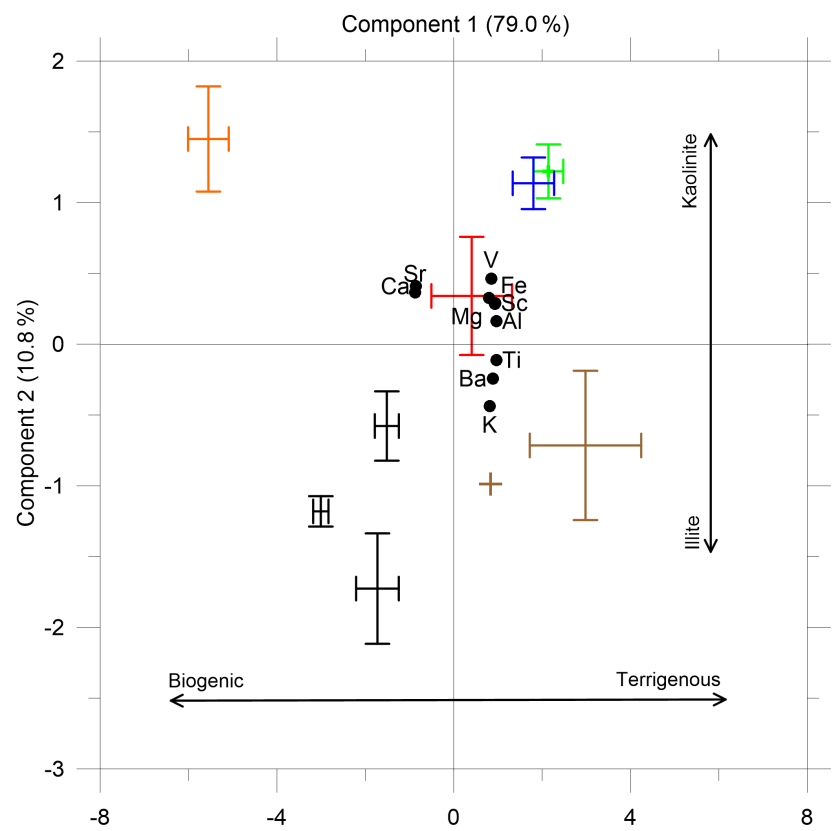

Figure 3. Biplot (samples and variables) of average \pm standard deviation of the first and second components of the principal component analysis of metals. Colours refer to samples from coast and inner shelf (brown), outer shelf and upper slope (black), relict outer shelf sediment (orange), upper slope - SACW (green), middle slope - IWBC (red) and middle slope - DWBC (blue).

With regard to molecular markers, TAR ratios (Fig. 5a) are higher than 1 for all of the studied samples, indicating a contribution of terrestrial higher plants to the study area, especially visible in core 61 , located on the inner shelf. The TAR values range between 1.0 and almost 20.0 on the shelf, with the widest range occurring solely in the innermost shelf sediments, while the slope shows TAR signals typically between 1.0 and 4.8. A similar trend of TAR distribution patterns can be deduced from the Terrestrial $n$-alkanes Index (TI) (Fig. 5a), with values higher than $100 \mu \mathrm{gC}^{-1}$ found in the inner shelf samples. In addition, a rapid progressive TI decrease toward deeper water is detected, with minimum 

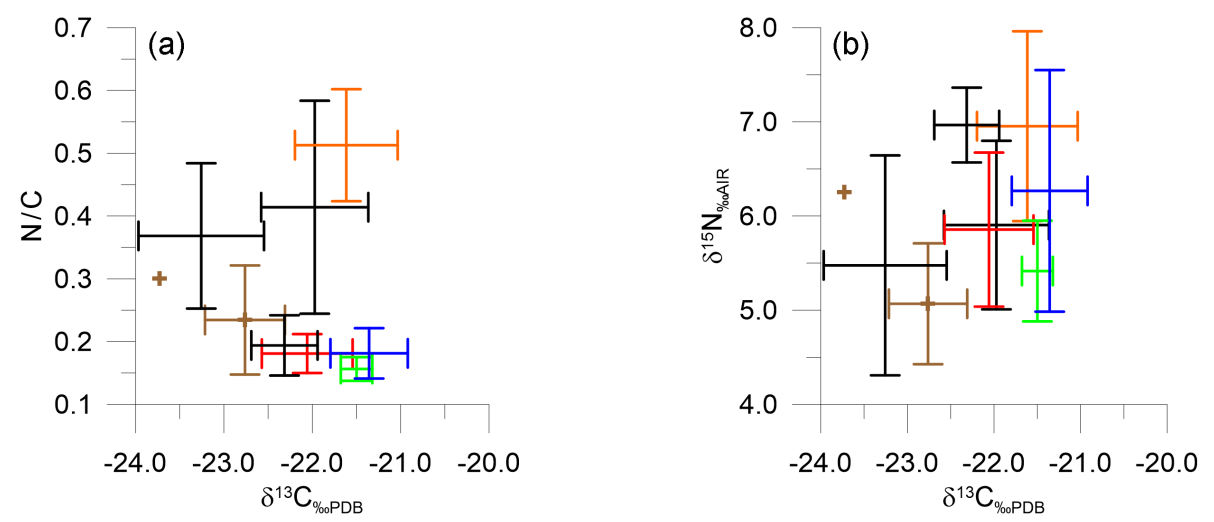

Figure 4. Scatter plots of average \pm standard deviation of (a) $\mathrm{N}_{\text {tot }} / \mathrm{C}_{\mathrm{org}}$ versus $\delta^{13} \mathrm{C}_{\% \circ \mathrm{PDB}}$ and (b) $\delta^{15} \mathrm{C}_{\% \circ \mathrm{AIR}}$ versus $\delta^{13} \mathrm{C}_{\% \circ \mathrm{PDB}}$. Colours refer to samples from coast and inner shelf (brown), outer shelf and upper slope (black), relict outer shelf sediment (orange), upper slope SACW (green), middle slope - IWBC (red) and middle slope - DWBC (blue).
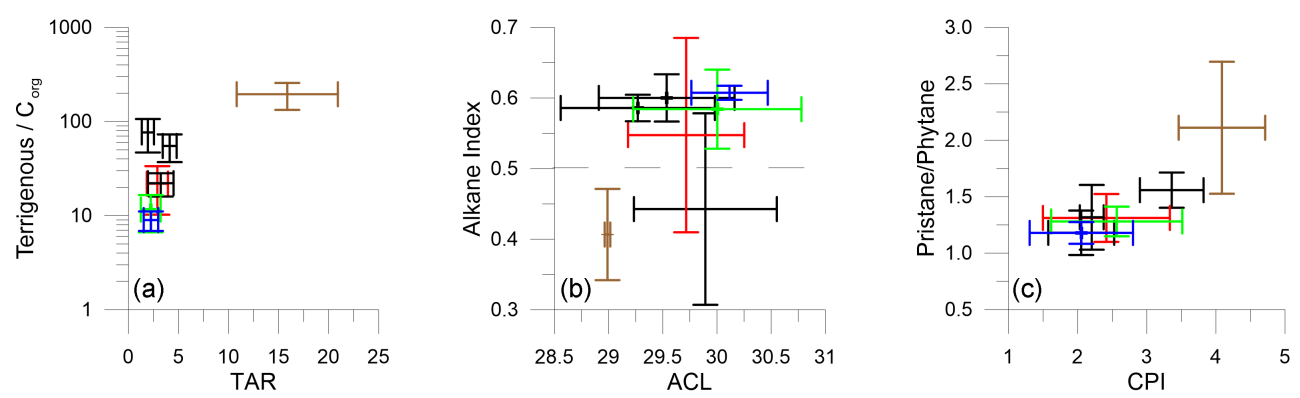

Figure 5. Scatter plot of average \pm standard deviation of (a) TI versus TAR, (b) AI versus ACL, and (c) Pr / Ph versus CPI. Colours refer to samples from the coast and inner shelf (brown), outer shelf and upper slope (black), relict outer shelf sediment (orange), upper slope SACW (green), middle slope - IWBC (red) and middle slope - DWBC (blue).

values around $4.4 \mu \mathrm{gCC}^{-1}$. Considering this last index, there is a dilution of about 16 times of $\mathrm{C}_{27-29-31}$ per $\mathrm{gC}$, from the inner shelf to the middle slope.

ACL values (Fig. 5 b) in all samples range from 28.96 to 33.00 , showing the presence of terrigenous influence in all sites. This ratio can also be used to infer the vegetation types that are dominant in the terrigenous source. Leaf lipids derived from grasslands have longer chain lengths than leaf lipids from forest plants (Cranwell, 1973). In rainforest $C_{3}$ plants, $n-\mathrm{C}_{29}$ dominates, whereas the dominant $n$-alkanes in $\mathrm{C}_{4}$ grasses are $n-\mathrm{C}_{31}$ and $n-\mathrm{C}_{33}$ (Rommerskirchen et al., 2006; Badewien et al., 2015). The average ACL values for sample 61 in shelf waters are typical of $\mathrm{C}_{3}$ plant influence and lower than those from the slope, mainly characterised by $n$-alkanes derived from $\mathrm{C}_{4}$ plants, which is corroborated by the AI ratio.

The Alkane Index (AI) (Fig. 5b) also shows a clear differentiation between shelf and slope, with the former showing an AI range between 0.25 and 0.56 and the latter with values higher than 0.55 (with the singular exception of core 63 at $840 \mathrm{~m}$ water depth). The AI has been used to investigate dominant inputs from $\mathrm{C}_{4}$ and $\mathrm{C}_{3}$ terrestrial plants. Vegetation dominated by grasses and herbs $\left(\mathrm{C}_{4}\right.$ plants $)$ normally presents AI values larger than 0.5. On the other hand, forest assemblages show AI values less than 0.5 (Schefuß et al., 2003). Accordingly, the organic matter of cores 61 and 62, located on the shelf, is dominated by input of $\mathrm{C}_{3}$ vegetation derived from the Atlantic rainforest adjacent to the sampling site. The cores from the slope show AI index values typical for grasses, which indicates that there is a difference in the contribution from terrigenous sources between slope and shelf, thus defining the limits of the contribution of the adjacent continent to sediment organic matter.

The Carbon Preference Index (CPI) (Fig. 5c) is a tool that indicates the $n$-alkane source. Normally, CPI values above 3 are associated with a strong predominance of compounds from land plant waxes (Clark Jr. and Blumer, 1967; Hedges and Prahl, 1993), while values close to 1 indicate $n$-alkanes mostly derived from phytoplankton, bacteria, recycled organic matter or petroleum (Clark Jr. and Blumer, 1967; Volkman et al., 1983; Kennicutt et al., 1987). From the CPI obtained for individual cores (Fig. 10) it is possible to observe that most samples from cores 61 and 62 show CPI values higher than 3, indicating a strong influence of terrigenous material. The other cores are characterised by lower CPI val- 


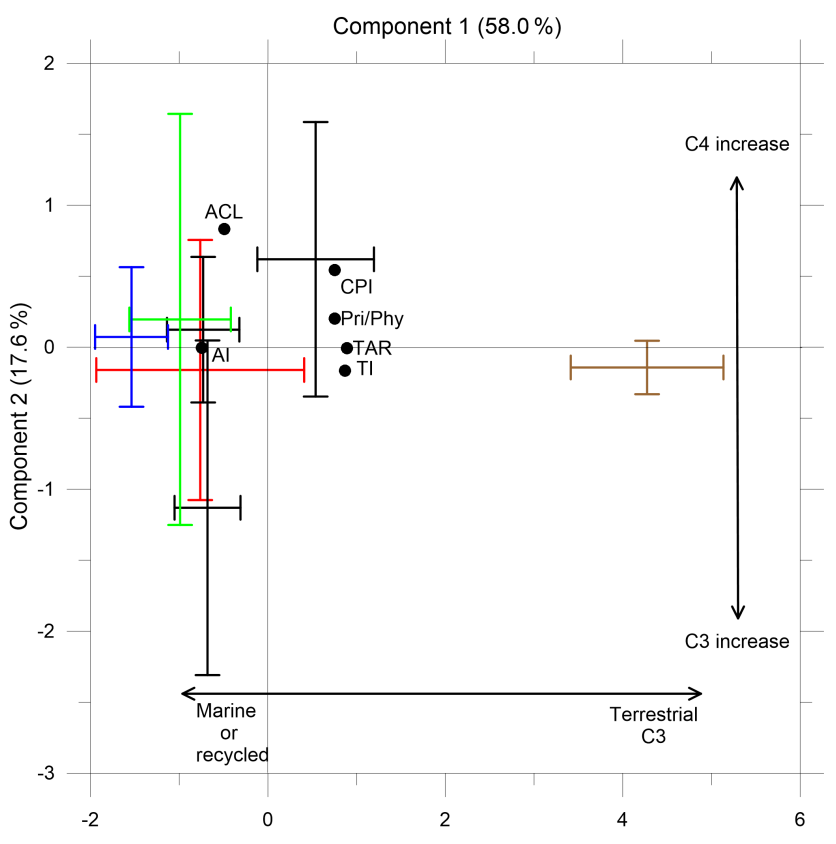

Figure 6. Biplot (samples and variables) of average \pm standard deviation of the first and second components of the principal component analysis of molecular markers. Colours refer to samples from the coast and inner shelf (brown), outer shelf and upper slope (black), relict outer shelf sediment (orange), upper slope - SACW (green), middle slope - IWBC (red) and middle slope - DWBC (blue).

ues, suggesting the contribution of either marine or recycled organic matter.

As a general rule, the pristane / phytane ratio (Pri / Phy) tends to increase with an increasing contribution of terrestrial organic matter (Rashid, 1979). Thus, the values obtained in this study, with a wide range in shelf waters, ranged between 1.3 and 2.8 , while with increasing water depth, the values vary between 0.9 and 1.3 , indicating a possible contribution of marine or recycled organic matter in deeper areas. Figure $5 \mathrm{c}$ shows a trend of decreasing values toward deeper areas, with highest values in NAP 61, corresponding to both TAR and TI distributions. Also, all the cores presented Pri / Phy values higher than 1 which, according to Didyk et al. (1978), indicate fully oxic conditions of the bottom waters in our study area. This ratio can also be affected by the presence of bacterial material (Volkman and Maxwell, 1986; Ten Haven et al., 1988).

The first two components of the PCA analysis for the molecular parameters (Fig. 6) account for $75.6 \%$ of the total variance of the system and allow us to synthesise the variations of terrestrial versus marine or recycled organic matter as well as of the relative contribution of $\mathrm{C} 3$ and $\mathrm{C} 4$ plants. Component 1 (58.0\% of the variance) distinguishes between shelf and slope samples, the first being characterised by higher values of TAR, TI, CPI and Pri / Phy, as well as lower values of ACL and AI. On the other hand, Component
$2(17.6 \%$ of the variance) separates samples from the upper and middle slopes, the latter marked by the highest values of ACL.

\subsection{Sediment sources and ocean circulation}

The south-eastern Brazilian shelf has frequently been classified as a "starving platform" (Kowsmann and Costa, 1979), with modern sediment cover considered the result of reworking transgressive sediments. Nevertheless, it is worth noting that there are mud depocentres, as defined by Hanebuth et al. (2015), in which muddy sedimentation can be significant and Holocene sedimentation rates can be higher than $50 \mathrm{~cm} \mathrm{kyr}^{-1}$ (de Mahiques et al., 2011; Mendoza et al., 2014; de Mahiques et al., 2016). The sources of these sediments are still a matter of debate, but a mixture of local and distant sources cannot be ignored (Mendoza et al., 2014).

The $\ln (\mathrm{Ti} / \mathrm{Al})$ versus $\ln (\mathrm{Fe} / \mathrm{K})$ ratios (Fig. 2b), $\ln (\mathrm{K} / \mathrm{Al}$ ) versus $\ln (\mathrm{Fe} / \mathrm{Ca}$ ) ratios (Fig. 2c), and the PCA of the metals (Fig. 3) indicate separate geochemical signatures for the shelf and slope sediments in the study area. The outer shelf relict facies is marked by higher $\mathrm{Ca}$ and $\mathrm{Sr}$ concentrations as well as a $\ln (\mathrm{Fe} / \mathrm{K})$ ratio higher than 0.8 . The coastal and inner shelves and upper slope signatures correspond to higher contents in $\mathrm{Ti}$ and $\mathrm{K}$. In this sense, and considering the humid climatic conditions along the south-eastern coast of South America, the coastal and shelf sediment values might reflect proximity to the source rock, i.e. the granitic and gneissic rocks of the adjacent continent (de Mahiques et al., 2016). This interpretation is in contrast to previous attempts linking element provenance patterns to limited chemical weathering on the adjacent continent (Mulitza et al., 2008; Just et al., 2012; Nace et al., 2014; Razik et al., 2015). Important to note is the fact that the geochemical signature of the shelf sediments is similar to that of the upper slope, at least down to the $370 \mathrm{~m}$ isobath, hinting at widespread continental supply even without a major fluvial source.

A more complex scenario is found for the sediments on the middle and lower continental slope. Considering all the inorganic proxies analysed, the sediments of core $63(840 \mathrm{~m}$ water depth) are geochemically distinct from those of cores 67 (649 m water depth) and 68 (1393 m water depth), which themselves are geochemically very similar to each other. The execution of a non-parametric Kruskal-Wallis analysis of variance (ANOVA) analysis also documents the significant differences between core 63 and the two others. According to Schmid et al. (2000), the site of core 63 is in the area of the IWBC, which is located between 800 and $1100 \mathrm{~m}$ water depth carrying AAIW to the north at these latitudes. This flow is in opposition to both the southward flowing BC, which carries SACW, as well as the DWBC, which transports NADW. Thus, the individual geochemical signal found at this particular location seems to be related to the nucleus of this intermediate current, delivering material from a remote sediment source along a clearly defined isobathic pathway. 


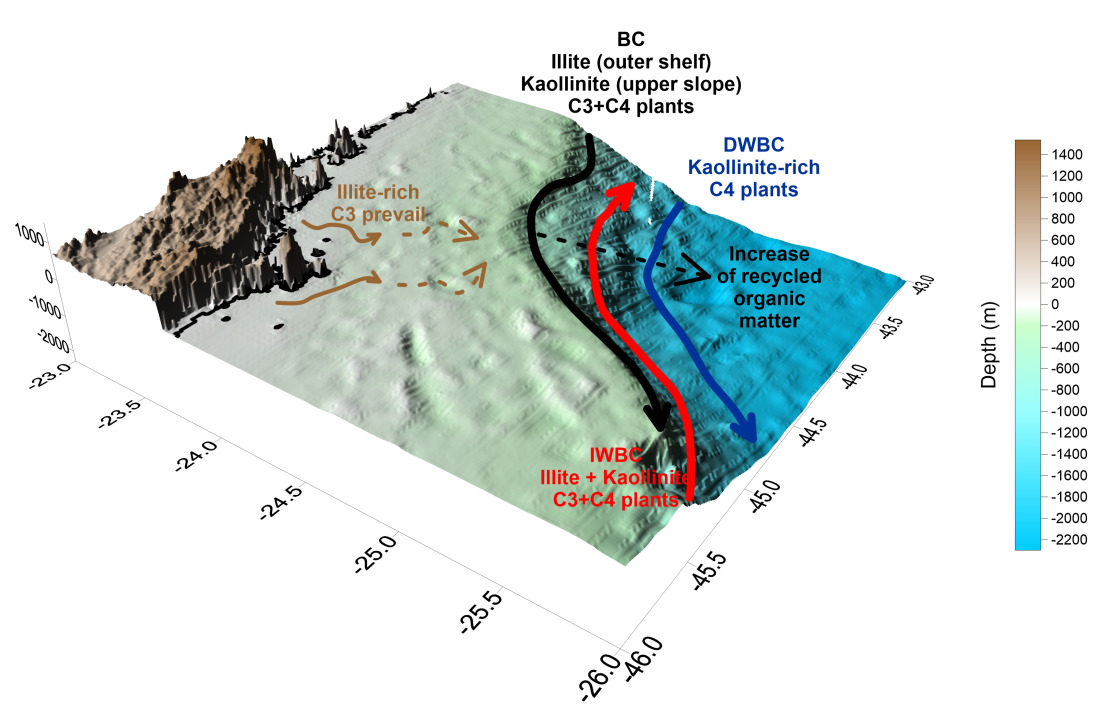

Figure 7. Conceptual model for the source and transport of inorganic and organic material in the study area.

A comparison of our data with those presented in Govin et al. (2012) clearly shows both comparable with their findings for the domains of the BC and DWBC, but essentially different from those from the intermediate levels, especially when comparing with those found by in the Argentinean margin, which, in fact, may extend to the Uruguayan margin (FrancoFraguas et al., 2016). This leads us to propose that the divergent flows of the IWBC generated by the Santos Bifurcation at approximately $28^{\circ} \mathrm{S}$ (Boebel et al., 1999) imprint a geochemical differentiation in the sediments, at intermediate levels, along the south-western Atlantic margin.

The picture that emerges from our analysis is then different from that presented by Razik et al. (2015). A possible explanation for this discrepancy might be related to the fact that the mechanisms thought to be responsible for lateral sediment transport in the present study are found in the complex vertical south-western Atlantic current circulation, and not in its water mass structure, as stated by those authors. In addition, the very limited number of samples $(n=2)$ used by Razik et al. for the same area might be one of the causes of this difference.

Finally, it is worth noting that samples from core 63 ( $840 \mathrm{~m}$ - IWBC) also slightly differ in the characteristics of the organic matter when compared with cores 67 (649 m BC) and 68 (1393 m-DWBC) (Figs. 3 and 6), corroborating the observation of a distinct remote sediment (and organic matter) source under the domain of the IWBC.

\subsection{Origin and characteristics of the organic matter}

We evaluated the relative contribution of terrestrial organic matter using the bulk organic $F_{\text {ter }}$ Index (Terrigenous Fraction) (Biscara et al., 2011). With regard to N/C, the distinction between shelf/upper slope and middle slope samples, including very high $\mathrm{N} / \mathrm{C}$ values found in the shelf sed- iments, may be an indicator of partial enrichment of both total and organic nitrogen during diagenetic processes (Müller, 1977; Álvarez-Salgado et al., 1997), as well as regeneration of nitrogen (Metzler et al., 1997). Concerning $\delta^{13} \mathrm{C}$, and assuming the end-members presented by de Mahiques et al. (1999) to be valid, the Fter estimates vary between $70 \%$ on the shelf and about $30 \%$ on the deeper slope, suggesting that the south-eastern Brazilian margin can receive excessive amounts of terrestrial organic matter, despite the lack of major adjacent rivers.

In addition, molecular proxies for the origin of the organic matter similarly indicate a relatively high input of terrigenous organic matter to the ocean. Regional rainfall is higher than $2000 \mathrm{~mm} \mathrm{yr}^{-1}$ (Fujieda et al., 1997), and the great potential of numerous small mountain rivers to supply terrestrial organic matter was already described by Leithold et al. (2006) and Goñi et al. (2013), among others, and was also addressed by de Mahiques et al. (1999) for the study area.

In order to compare the quality of the organic matter deposited on the area, plots of both ACL versus AI (Fig. 4b) and CPI versus Pri / Phy (Fig. 4c) show the difference between shelf and slope samples, with $\mathrm{C}_{3}$ plants prevailing as the main source of terrigenous organic matter in the shelf sediments, as indicated in previous studies (Rommerskirchen et al., 2006; Zhang et al., 2006). In contrast, almost all of the samples collected on the slope show AI values higher than 0.55 , indicating that $\mathrm{C}_{4}$ plants are the main source of the terrigenous fraction in the deeper deposits and, thus, suggesting that the source of organic matter is distinct from that of the adjacent continent. The origin of this organic matter probably corresponds to the areas of eastern and north-eastern Brazil, characterised by drier continental conditions (Ledru et al., 2006; Maioli et al., 2012) and carried by both BC and DWBC since they can transport sediments from further north. 
The gathering of both inorganic and organic information leads us to propose a conceptual model for signatures and transport agents of the study area (Fig. 7), enhancing the distinct geochemical signatures of the slope contour currents as well as the input of terrigenous organic matter to the shelf and upper slope and its increasing recycling towards deeper areas.

\section{Conclusions}

In this study, we used inorganic and organic parameters in sediment cores from the south-eastern South American margin to analyse both ocean current circulation and terrestrial material contribution patterns. The results reveal a regional input of terrigenous sediments that covers both the continental shelf and upper slope, down to close to the $400 \mathrm{~m}$ isobath.

We were also able to differentiate the geochemical signatures associated with northward transport by the Intermediate Western Boundary Current, in comparison with the southward displacements of the Brazil Current and Deep Western Boundary Current.

Based on bulk organic indicators, the percentage of terrestrial organic matter varies from $70 \%$, on the shelf, to $30 \%$ on the middle slope. Molecular markers indicate that input of terrestrial material is an important contributor to the organic matter deposited on both shelf and slope. In addition, molecular proxies indicate important differences in the sources of terrestrial organic matter. Shelf and upper slope sediments show a higher contribution of $\mathrm{C}_{3}$ plants, while $\mathrm{C}_{4}$ plant material characterises the deeper slope sediments.

Finally, a conceptual model for geochemical signatures and transport agents acting on the study area is presented.

Data availability. All of the data used are presented as the Supplement.

\section{The Supplement related to this article is available online at doi:10.5194/os-13-209-2017-supplement.}

Competing interests. The authors declare that they have no conflict of interest.

Acknowledgements. Financial support was provided by the São Paulo Science Foundation (FAPESP), grants 2010/06147-5 and 2015/21834-2, and the University of São Paulo via the NAPGEOSEDEX programme. Michel Michaelovitch de Mahiques acknowledges CNPq (grant 303132/2014-0). Thanks are due to the crew and researchers on board RV Alpha Crucis.

The authors also thank Nathalie Fagel (University of Liège) and an anonymous reviewer for their careful read and excellent suggestions.
Edited by: P. Chapman

Reviewed by: N. Fagel and one anonymous referee

\section{References}

Aboul-Kassim, T. A. T. and Simoneit, B. R. T.: Lipid geochemistry of surficial sediments from the coastal environment of Egypt I. Aliphatic hydrocarbons - characterization and sources, Mar. Chem., 54, 135-158, 1996.

Almeida, F. F. M. and Carneiro, C. D. R.: Origem e evolução da Serra do Mar, Brazilian Journal of Geology, 28, 135-150, 1998.

Álvarez-Salgado, X. A., Castro, C. G., Pérez, F. F., and Fraga, F.: Nutrient mineralization patterns in shelf waters of the Western Iberian upwelling, Cont. Shelf Res., 17, 1247-1270, 1997.

Badewien, T., Vogts, A., Dupont, L., and Rullkötter, J.: Influence of Late Pleistocene and Holocene climate on vegetation distributions in southwest Africa elucidated from sedimentary n-alkanes - Differences between $12^{\circ} \mathrm{S}$ and $20^{\circ} \mathrm{S}$, Quaternary Sci. Rev., 125, 160-171, 2015.

Bi, X., Sheng, G., Liu, X., Li, C., and Fu, J.: Molecular and carbon and hydrogen isotopic composition of n-alkanes in plant leaf waxes, Organic Geochemistry, 36, 1405-1417, 2005.

Bicego, M. C., Taniguchi, S., Yogui, G. T., Montone, R. C., Moreira da Silva, D. A., Lourenco, R. A., de Castro Martins, C., Sasaki, S. T., Pellizari, V. H., and Weber, R. R.: Assessment of contamination by polychlorinated biphenyls and aliphatic and aromatic hydrocarbons in sediments of the Santos and Sao Vicente Estuary System, Sao Paulo, Brazil, Mar. Pollut. Bull., 52, 1804-1816, 2006.

Biló, T. C., da Silveira, I. C. A., Belo, W. C., de Castro, B. M., and Piola, A. R.: Methods for estimating the velocities of the Brazil Current in the pre-salt reservoir area off southeast Brazil $\left(23^{\circ} \mathrm{S}-\right.$ $\left.26^{\circ} \mathrm{S}\right)$, Ocean Dynam., 64, 1431-1446, 2014.

Biscara, L., Mulder, T., Martinez, P., Baudin, F., Etcheber, H., Jouanneau, J.-M., and Garlan, T.: Transport of terrestrial organic matter in the Ogooué deep sea turbidite system (Gabon), Mar. Petrol. Geol., 28, 1061-1072, 2011.

Boebel, O., Schmid, C., and Zenk, W.: Flow and recirculation of Antarctic Intermediate Water across the Rio Grande Rise, J. Geophys. Res.-Oceans, 102, 20967-20986, 1997.

Boebel, O., Davis, R. E., Ollitrault, M., Peterson, R. G., Richardson, P. L., Schmid, C., and Zenk, W.: The intermediate depth circulation of the western South Atlantic, Geophys. Res. Lett., 26, 3329-3332, 1999.

Boggs, S. J.: Principles of Sedimentology and Stratigraphy, Prentice Hall, New York, 2005.

Bourbonniere, R. A. and Meyers, P. A.: Anthropogenic influences on hydrocarbon contents of sediments deposited in eastern Lake Ontario since 1800, Environ. Geol., 28, 22-28, 1996.

Campos, E. J. D., Lentini, C. A. D., Miller, J. L., and Piola, A. R.: Interannual variability of the sea surface temperature in the South Brazil Bight, Geophys. Res. Lett., 26, 2061-2064, 1999.

Ciotti, Á. M., Odebrecht, C., Fillmann, G., and Moller, O. O.: Freshwater outflow and Subtropical Convergence influence on phytoplankton biomass on the southern Brazilian continental shelf, Cont. Shelf Res., 15, 1737-1756, 1995. 
Clark Jr., R. C. and Blumer, M.: Distribution of n-paraffins in marine organisms and sediment, Limnol. Oceanogr., 12, 79-87, 1967.

Collister, J. W., Rieley, G., Stern, B., Eglinton, G., and Fry, B.: Compound-specific $\delta 13 \mathrm{C}$ analyses of leaf lipids from plants with differing carbon dioxide metabolisms, Organic Geochem., 21, 619-627, 1994.

Colombo, J. C., Pelletier, E., Brochu, C., Khalil, M., and Catoggio, J. A.: Determination of hydrocarbon sources using n-alkane and polyaromatic hydrocarbon distribution indexes. Case study: Rio de la Plata Estuary, Argentina, Environ. Sci. Technol., 23, 888894, 1989.

Cranwell, P. A.: Chain-length distribution of n-alkanes from lake sediments in relation to post-glacial environmental change, Freshwater Biol., 3, 259-265, 1973.

de Mahiques, M. M., Mishima, Y., and Rodrigues, M.: Characteristics of the sedimentary organic matter on the inner and middle continental shelf between Guanabara Bay and São Francisco do Sul, southeastern Brazilian margin, Cont. Shelf Res., 19, 775798, 1999.

de Mahiques, M. M., Tessler, M. G., Maria Ciotti, A., da Silveira, I. C. A., e Sousa, S. H. d. M., Figueira, R. C. L., Tassinari, C. C. G., Furtado, V. V., and Passos, R. F.: Hydrodynamically driven patterns of recent sedimentation in the shelf and upper slope off Southeast Brazil, Cont. Shelf Res., 24, 1685-1697, 2004.

de Mahiques, M. M., Tassinari, C. C. G., Marcolini, S., Violante, R. A., Figueira, R. C. L., da Silveira, I. C. A., Burone, L., and de Mello e Sousa, S. H.: Nd and Pb isotope signatures on the Southeastern South American upper margin: Implications for sediment transport and source rocks, Mar. Geol., 250, 51-63, 2008.

de Mahiques, M. M., Sousa, S. H. M., Burone, L., Nagai, R. H., Silveira, R. C. L., Soutelino, R. G., Ponsoni, L., and Klein, D. A.: Radiocarbon geochronology of the sediments of the São Paulo Bight (southern Brazilian upper margin), An Acad Bras Cienc, 83, 817-834, 2011.

de Mahiques, M. M., Hanebuth, T. J. J., Martins, C. C., MontoyaMontes, I., Alcántara-Carrió, J., Figueira, R. C. L., and Bícego, M. C.: Mud depocentres on the continental shelf: a neglected sink for anthropogenic contaminants from the coastal zone, Environ. Earth Sci., 75, doi:10.1007/s12665-015-4782-z, 2016.

de Souza, R. B. and Robinson, I. S.: Lagrangian and satellite observations of the Brazilian Coastal Current, Cont. Shelf Res., 24, 241-262, 2004.

Didyk, B. M., Simoneit, B. R. T., Brassell, S. C., and Eglinton, G.: Organic geochemical indicators of palaeoenvironmental conditions of sedimentation, Nature, 272, 216-222, 1978.

Dottori, M. and Castro, B. M.: The response of the Sao Paulo Continental Shelf, Brazil, to synoptic winds, Ocean Dynam/, 59, 603614, 2009.

Eglinton, G. and Hamilton, R. J.: The distribution of n-alkanes, in: Chemical Plant Taxonomy, edited by: Swain, T., Academic Press, 1963.

Eglinton, G., Hamilton, R. J., Raphael, R. A., and Gonzalez, A. G.: Hydrocarbon constituents of the wax coatings of plant leaves: a taxonomic survey, Nature, 193, 739-742, 1962.

Ficken, K. J., Li, B., Swain, D. L., and Eglinton, G.: An n-alkane proxy for the sedimentary input of submerged/floating freshwater aquatic macrophytes, Organic Geochem., 31, 745-749, 2000.
Franco-Fraguas, P., Burone, L., Mahiques, M., Ortega, L., Urien, C., Muñoz, A., López, G., Marin, Y., Carranza, A., Lahuerta, N., and de Mello, C.: Hydrodynamic and geomorphological controls on surface sedimentation at the Subtropical Shelf Front / BrazilMalvinas Confluence transition off Uruguay (Southwestern Atlantic Continental Margin), Mar. Geol., 349, 24-36, 2014.

Franco-Fraguas, P., Burone, L., Mahiques, M., Ortega, L., and Carranza, A.: Modern sedimentary dynamics in the Southwestern Atlantic Contouritic Depositional System: New insights from the Uruguayan margin based on a geochemical approach, Mar. Geol., 376, 15-25, doi:10.1016/j.margeo.2016.03.008, 2016.

Fujieda, M., Kudoh, T., de Cicco, V., and de Calvarcho, J. L.: Hydrological processes at two subtropical forest catchments: the Serra do Mar, São Paulo, Brazil, J. Hydrol., 196, 26-46, 1997.

Goñi, M. A., Hatten, J. A., Wheatcroft, R. A., and Borgeld, J. C.: Particulate organic matter export by two contrasting small mountainous rivers from the Pacific Northwest, U.S.A, J. Geophys. Res.-Biogeosc., 118, 112-134, 2013.

Govin, A., Holzwarth, U., Heslop, D., Ford Keeling, L., Zabel, M., Mulitza, S., Collins, J. A., and Chiessi, C. M.: Distribution of major elements in Atlantic surface sediments $\left(36^{\circ} \mathrm{N}-49^{\circ} \mathrm{S}\right)$ : Imprint of terrigenous input and continental weathering, Geochem. Geophy. Geosy., 13, Q01013, doi:10.1029/2011GC003785, 2012.

Hammer, Ø., Harper, D. A. T., and Ryan, P. D.: PAST: Paleontological statistics software package for education and data analysis, Palaeontologia Electronica, 4, 9 pp., 2001.

Hanebuth, T. J. J., Lantzsch, H., and Nizou, J.: Mud depocenters on continental shelves - appearance, initiation times, and growth dynamics, Geo-Marine Lett., 35, 487-503, 2015.

Hedges, J. I. and Prahl, F. G.: Early Diagenesis: Consequences for Applications of Molecular Biomarkers, in: Organic Chemistry: Principles and Applications, edited by: Engel, M. H. and Macko, S. A., Springer, New York, 1993.

Hernandez-Molina, F. J., Paterlini, M., Violante, R., Marshall, P., de Isasi, M., Somoza, L., and Rebesco, M.: Contourite depositional system on the Argentine Slope: An exceptional record of the influence of Antarctic water masses, Geology, 37, 507-510, 2009.

Holz, C., Stuut, J.-B. W., and Henrich, R.: Terrigenous sedimentation processes along the continental margin off NW Africa: implications from grain-size analysis of seabed sediments, Sedimentology, 51, 1145-1154, 2004.

Horikawa, K., Murayama, M., Minagawa, M., Kato, Y., and Sagawa, T.: Latitudinal and downcore $(0-750 \mathrm{ka})$ changes in $\mathrm{n}-$ alkane chain lengths in the eastern equatorial Pacific, Quaternary Res., 73, 573-582, 2010.

Jeng, W.-L.: Higher plant n-alkane average chain length as an indicator of petrogenic hydrocarbon contamination in marine sediments, Marine Chem., 102, 242-251, 2006.

Just, J., Heslop, D., von Dobeneck, T., Bickert, T., Dekkers, M. J., Frederichs, T., Meyer, I., and Zabel, M.: Multiproxy characterization and budgeting of terrigenous end-members at the NW African continental margin, Geochem. Geophy. Geosy., 13, Q0AO01, doi:10.1029/2012GC004148, 2012.

Kennicutt, M. C., Sericano, J. L., Wade, T. L., Alcazar, F., and Brooks, J. M.: High molecular weight hydrocarbons in Gulf of Mexico continental slope sediments, Deep Sea Res. Part A, 34, 403-424, 1987. 
Kowsmann, R. O. and Costa, M. P. A.: Sedimentação Quaternária da Margem Continental Brasileira e das Areas Adjacentes, Petrobrás, Rio de Janeiro, 1979.

Lacan, F. and Jeandel, C.: Neodymium isotopes as a new tool for quantifying exchange fluxes at the continent-ocean interface, Earth Planet. Sci. Lett., 232, 245-257, 2005.

Ledru, M.-P., Ceccantini, G., Gouveia, S. E. M., López-Sáez, J. A., Pessenda, L. C. R., and Ribeiro, A. S.: Millenial-scale climatic and vegetation changes in a northern Cerrado (Northeast, Brazil) since the Last Glacial Maximum, Quaternary Sci. Rev., 25, 1110-1126, 2006.

Legeais, J.-F., Ollitrault, M., and Arhan, M.: Lagrangian observations in the Intermediate Western Boundary Current of the South Atlantic, Deep Sea Res. Part II, 85, 109-126, 2013.

Leithold, E. L., Blair, N. E., and Perkey, D. W.: Geomorphologic controls on the age of particulate organic carbon from small mountainous and upland rivers, Global Biogeochem. Cy., 20, GB3022, doi:10.1029/2005GB002677, 2006.

Lund, D. C., Tessin, A. C., Hoffman, J. L., and Schmittner, A.: Southwest Atlantic water mass evolution during the last deglaciation, Paleoceanography, 30, 477-494, 2015.

Maia, R. M. C., Reis, A. T., Alves, E. C., Silva, C. G., Guerra, J. V., Gorini, C., Silva, A., and Arantes-Oliveira, R.: Architecture and stratigraphic framework of shelf sedimentary systems off Rio de Janeiro State, northen Santos Basin - Brazil, Brazilian Journal of Oceanography, 58(SI), 15-29, 2010.

Maioli, O. L. G., de Oliveira, C. R., Dal Sasso, M. A., Madureira, L. A. d. S., Azevedo, D. d. A., and de Aquino Neto, F. R.: Evaluation of the organic matter sources using the $\delta 13 \mathrm{C}$ composition of individual $\mathrm{n}$-alkanes in sediments from Brazilian estuarine systems by GC/C/IRMS, Estuarine, Coast. Shelf Sci., 114, 140-147, 2012.

Meisling, K. E., Cobbold, P. R., and Mount, V. S.: Segmentation of an obliquely rifted margin, Campos and Santos basins, southeastern Brazil, AAPG Bulletin, 85, 1903-1924, 2001.

Mendoza, U., Ayres Neto, A., Abuchacra, R. C., Barbosa, C. F., Figueiredo, A. G, Gomes, M. C., Belem, A. L., Capilla, R., and Albuquerque, A. L.: Geoacoustic character, sedimentology and chronology of a cross-shelf Holocene sediment deposit off Cabo Frio, Brazil (southwest Atlantic Ocean), Geo-Marine Lett., 34, 297-314, 2014.

Metzler, P. M., Glibert, P. M., Gaeta, S. A., and Ludlam, J. M.: New and regenerated production in the South Atlantic off Brazil, Deep Sea Res. Part I, 44, 363-384, 1997.

Meyers, P. A.: Preservation of elemental and isotopic source identification of sedimentary organic matter, Chem. Geol., 114, 289302, 1994

Möller, O. O., Piola, A. R., Freitas, A. C., and Campos, E. J. D.: The effects of river discharge and seasonal winds on the shelf off southeastern South America, Cont. Shelf Res., 28, 1607-1624, 2008.

Moser, G. A. O., Takanohashi, R. A., de Chagas Braz, M., de Lima, D. T., Kirsten, F. V., Guerra, J. V., Fernandes, A. M., and Pollery, R. C. G.: Phytoplankton spatial distribution on the Continental Shelf off Rio de Janeiro, from Paraíba do Sul River to Cabo Frio, Hydrobiologia, 728, 1-21, 2014.

Mulitza, S., Prange, M., Stuut, J.-B., Zabel, M., von Dobeneck, T., Itambi, A. C., Nizou, J., Schulz, M., and Wefer, G.: Sahel megadroughts triggered by glacial slowdowns of At- lantic meridional overturning, Paleoceanography, 23, PA4206, doi:10.1029/2008PA001637, 2008.

Müller, P. J.: C/N ratios in Pacific deep-sea sediments: Effect of inorganic ammonium and organic nitrogen compounds sorbed by clays, Geochim. Cosmochim. Acta, 41, 765-776, 1977.

Nace, T. E., Baker, P. A., Dwyer, G. S., Silva, C. G., Rigsby, C. A., Burns, S. J., Giosan, L., Otto-Bliesner, B., Liu, Z., and Zhu, J.: The role of North Brazil Current transport in the paleoclimate of the Brazilian Nordeste margin and paleoceanography of the western tropical Atlantic during the late Quaternary, Palaeogeogr. Palaeoclimatol. Palaeoecol., 415, 3-13, 2014.

Nagai, R. H., Ferreira, P. A. L., Mulkherjee, S., Martins, M. V., Figueira, R. C. L., Sousa, S. H. M., and Mahiques, M. M.: Hydrodynamic controls on the distribution of surface sediments from the southeast South American continental shelf between $23^{\circ} \mathrm{S}$ and $38^{\circ}$ S, Cont. Shelf Res., 89, 51-60, 2014a.

Nagai, R. H., Sousa, S. H. M., and Mahiques, M. M.: Chapter 5 The southern Brazilian shelf, Geological Society, London, Memoirs, 41, 47-54, 2014b.

Nittrouer, C. A., Austin, J. A., Field, M. E., Kravitz, J. H., Syvitski, J. P. M., and Wiberg, P. L.: Continental Margin Sedimentation: From Sediment Transport to Sequence Stratigraphy, Blackwell Publishing Ltd., New York, 2007.

Nunes, M. C. V., Viviers, M. C., and Lana, C. C.: Bacias Sedimentares Brasileiras, Bacia de Santos, Fundação Paleontológica Phoenix, Aracaju, Brazil, 2004.

Perdue, E. M. and Koprivnjak, J.-F.: Using the $\mathrm{C} / \mathrm{N}$ ratio to estimate terrigenous inputs of organic matter to aquatic environments, Estuar. Coast. Shelf Sci., 73, 65-72, 2007.

Petschick, R., Kuhn, G., and Gingele, F.: Clay mineral distribution in surface sediments of the South Atlantic: sources, transport, and relation to oceanography, Marine Geol., 130, 203-229, 1996.

Pietrogrande, M. C., Mercuriali, M., Perrone, M. G., Ferrero, L., Sangiorgi, G., and Bolzacchini, E.: Distribution of n-alkanes in the Northern Italy aerosols: data handling of GC-MS signals for homologous series characterization, Environ. Sci. Technol., 44, 4232-4240, 2010.

Plewa, K., Meggers, H., Kuhlmann, H., Freudenthal, T., Zabel, M., and Kasten, S.: Geochemical distribution patterns as indicators for productivity and terrigenous input off NW Africa, Deep Sea Res. Part I, 66, 51-66, 2012.

Powell, T. G. and McKirdy, D. M.: Relationship between Ratio of Pristane to Phytane, Crude Oil Composition and Geological Environment in Australia, Nature Phys. Sci., 243, 37-39, 1973.

Poynter, J. and Eglinton, G.: Molecular composition of three sediments from hole 717C: The Bengal Fan, in: Proceedings of the Ocean Drilling Program, Scientific Results, edited by: Cochran, J. R. and Stow, D. A. V., Ocean Drilling Program, College Station, 1990.

Pratson, L. F., Nittrouer, C. A., Wiberg, P. L., Steckler, M. S., Swenson, J. B., Cacchione, D. A., Karson, J. A., Murray, A. B., Wolinsky, M. A., Gerber, T. P., Mullenbach, B. L., Spinelli, G. A., Fulthorpe, C. S., O'grady, D. B., Parker, G., Driscoll, N. W., Burger, R. L., Paola, C., Orange, D. L., Field, M. E., Friedrichs, C. T., and Fedele, J. J.: Seascape Evolution on Clastic Continental Shelves and Slopes, in: Continental Margin Sedimentation: From Sediment Transport to Sequence Stratigraphy, edited by: Nittrouer, C. A., Austin, J. A., Field, M. E., Kravitz, J. H., Syvit- 
ski, J. P. M., and Wiberg, P. L., Blackwell Publishing Ltd, Oxford, UK, 2007.

Prins, M. A. and Weltje, G. J.: End-Member Modeling of Siliciclastic Grain-Size Distributions: The Late Quaternary Record of Eolian and Fluvial Sediment Supply to the Arabian Sea and Its Paleoclimatic Significance, in: Numerical Experiments in Stratigraphy Recent Advances in Stratigraphic and Sedimentologic Computer Simulations. SEPM Special Publications No 63, SEPM, University of Kansas, 1999.

Rashid, M. A.: Pristane-phytane ratios in relation to source and diagenesis of ancient sediments from the Labrador Shelf, Chem. Geol., 25, 109-122, 1979.

Razik, S., Govin, A., Chiessi, C. M., and von Dobeneck, T.: Depositional provinces, dispersal, and origin of terrigenous sediments along the SE South American continental margin, Marine Geol., 363, 261-272, 2015.

Reis, A. T., Maia, R. M. C., Silva, C. G., Rabineau, M., Guerra, J. V., Gorini, C., Ayres, A., Arantes-Oliveira, R., Benabdellouahed, M., Simões, I., and Tardin, R.: Origin of step-like and lobate seafloor features along the continental shelf off Rio de Janeiro State, Santos basin-Brazil, Geomorphology, 203, 25-45, 2013.

Rommerskirchen, F., Eglinton, G., Dupont, L., and Rullkötter, J.: Glacial/interglacial changes in southern Africa: Compoundspecific $\delta 13 \mathrm{C}$ land plant biomarker and pollen records from southeast Atlantic continental margin sediments, Geochem. Geophy. Geosy., 7, Q08010, doi:10.1029/2005GC001223, 2006.

Ruttenberg, K. C. and Goñi, M. A.: Phosphorus distribution, C:N:P ratios, and $\delta 13 \mathrm{Coc}$ in arctic, temperate, and tropical coastal sediments: tools for characterizing bulk sedimentary organic matter, Marine Geol., 139, 123-145, 1997.

Schattner, U., Lazar, M., Souza, L. A. P., ten Brink, U., and Mahiques, M. M.: Pockmark asymmetry and seafloor currents in the Santos Basin offshore Brazil, Geo-Marine Lett., 36, doi:10.1007/s00367-016-0468-0, 2016.

Schefuß, E., Ratmeyer, V., Stuut, J.-B. W., Jansen, J. H. F., and Sinninghe Damsté, J. S.: Carbon isotope analyses of n-alkanes in dust from the lower atmosphere over the central eastern Atlantic, Geochim. Cosmochim. Acta, 67, 1757-1767, 2003.

Schmid, C., Siedler, G., and Zenk, W.: Dynamics of Intermediate Water Circulation in the Subtropical South Atlantic*, J. Phys. Oceanogr., 30, 3191-3211, 2000.

Silveira, I. C. A. D., Schmidt, A. C. K., Campos, E. J. D., Godoi, S. S. D., and Ikeda, Y.: A corrente do Brasil ao largo da costa leste brasileira, Revista Brasileira de Oceanografia, 48, 171-183, 2000 .

Silveira, I. C. A., Calado, L., Castro, B. M., Cirano, M., Lima, J. A. M., and Mascarenhas, A. D. S.: On the baroclinic structure of the Brazil Current-Intermediate Western Boundary Current system at $22^{\circ}-23^{\circ} \mathrm{S}$, Geophys. Res. Lett., 31, L14308, doi:10.1029/2004GL020036, 2004.

Stow, D. A. V., Hunter, S., Wilkinson, D., and Hernandez-Molina, F. J.: The Nature of Contourite Deposition, in: Developments in Sedimentology, edited by: Rebesco, M. C. and Camerlenghi, A., Elsevier, Amsterdam, 2008.
Stramma, L. and England, M.: On the water masses and mean circulation of the South Atlantic Ocean, J. Geophys. Res.-Oceans, 104, 20863-20883, 1999.

Suguio, K. and Martin, L.: Quaternary marine formations of the State of São Paulo and southern Rio de Janeiro, São Paulo, 1-55, 1978.

Sumida, P. Y. G., Yoshinaga, M. Y., Ciotti, A. M., and Gaeta, S. A.: Benthic response to upwelling events off the SE Brazilian coast, Mar. Ecol. Prog. Ser., 291, 35-42, 2005.

Sun, Y., Wu, F., Clemens, S. C., and Oppo, D. W.: Processes controlling the geochemical composition of the South China Sea sediments during the last climatic cycle, Chem. Geol., 257, 240-246, 2008.

Ten Haven, H. L., Rullkötter, J., De Leeuw, J. W., and Damsté, J. S. S.: Pristane/phytane ratio as environmental indicator, Nature, 333, 604-604, 1988.

Vogts, A., Moossen, H., Rommerskirchen, F., and Rullkötter, J.: Distribution patterns and stable carbon isotopic composition of alkanes and alkan-1-ols from plant waxes of African rain forest and savanna C3 species, Organic Geochemistry, 40, 1037-1054, 2009.

Volkman, J. K. and Maxwell, J. R.: Acyclic isoprenoids as biological markers, in: Biological markers in the sedimentary record, edited by: Johns, R. B., Elsevier, Amsterdam, 1986.

Volkman, J. K., Alexander, R., Kagi, R. I., and Woodhouse, G. W.: Demethylated hopanes in crude oils and their applications in petroleum geochemistry, Geochim. Cosmochim. Acta, 47, 785794, 1983.

Vroon, P. Z., van Bergen, M. J., Klaver, G. J., and White, W. M.: Strontium, neodymium, and lead isotopic and trace-element signatures of the East indonesian sediments: provenance and implications for banda arc magma genesis, Geochim. Cosmochim. Acta, 59, 2573-2598, 1995.

Wahsner, M., Müller, C., Stein, R., Ivanov, G., Levitan, M., Shelekhova, E., and Tarasov, G.: Clay-mineral distribution in surface sediments of the Eurasian Arctic Ocean and continental margin as indicator for source areas and transport pathways - a synthesis, Boreas, 28, 215-233, 1999.

Wilson, B.: The significance of iron-stained foraminifera off SE Trinidad, West Indies, western central Atlantic Ocean, Geological Magazine, 147, 728-736, 2010.

Zembruscki, S. G.: Geomorfologia da margem continental sul brasileira e das bacias oceânicas adjacentes, in: Geomorfologia da margem continental brasileira e áreas oceânicas adjacentes, edited by: Chaves, H. A. F., 7, Petrobrás, Rio de Janeiro, 1979.

Zhang, Z., Zhao, M., Eglinton, G., Lu, H., and Huang, C.: Leaf wax lipids as paleovegetational and paleoenvironmental proxies for the Chinese Loess Plateau over the last 170 kyr, Quaternary Sci. Rev., 25, 575-594, 2006. 